Deborah J. Dehring MD, Bhagwandas Gupta MD, William T. Peruzzi MD

\title{
Postoperative opisthoto- nus and torticollis after fentanyl, enfiurane, and nitrous oxide
}

\begin{abstract}
Most drug-induced extrapyramidal symptoms are due to blockade of dopaminergic receptors and are treated with anticholinergic drugs. We report a patient with severe postoperative extrapyramidal symptoms which responded to physostigmine and indicated a different aetiology. A young, healthy female outpatient developed severe extrapyramidal symptoms after an uneventful 50 min anaesthetic with thiopentone, fentanyl (100 $\mu \mathrm{g})$, enflurane, and nitrous oxide. Although the trachea was not extubated until she obeyed commands, the patient developed opisthotonus, which resolved initially after treatment with thiopentone $(40 \mathrm{mg})$, diazepam $(5 \mathrm{mg})$, and diphenhydramine (50 mg). The opisthotonus recurred approximately 25 min later, in association with torticollis, obtundation, and periodic apnoea. A tentative diagnosis of central anticholinergic syndrome was proposed, and fentanyl was considered to have been responsible. Naloxone $(0.4 \mathrm{mg})$ induced no improvement, but physostigmine $(2 \mathrm{mg})$ reversed the dystonic symptoms and periodic apnoea and improved her mental status. The response to physostigmine may have been due specifically to increased levels of acetylcholine at the cholinergic receptors, or to a nonspecific analeptic effect.
\end{abstract}

\section{Key words}

ANAESTHETICS, GASES: nitrous oxide;

ANAESTHETICS, INTRAVENOUS: fentanyl;

ANAESTHETICS, VOLATILE: enflurane;

ANTAGONISTS, NARCOTIC: naloxone;

ANTAGONISTS, MISCELLANEOUS: physostigmine;

CENTRAL NERVOUS SYSTEM: extrapyramidal system

symptoms and central anticholinergic syndrome; MUSCLE: rigidity.

From the Departments of Anesthesiology, University of Texas Medical Branch, Galveston, Texas; Ohio State University, Columbus, Ohio; Northwestern University Medical School, Chicago, Illinois.

Address correspondence to: Deborah J. Dehring, Associate Professor, Department of Anesthesiology, E-91, University of Texas Medical Branch, Galveston, Texas 77550-2778.

Accepted for publication 17th May, 1991.
La plupart des symptômes extrapyramidaux reliés à l'usage de médicaments sont causés par un blocage des récepteurs dopaminergiques et répondent bien aux anticholinergiques. Nous avons observé en postopératoire desmanifestations extrapyramidales répondant à l'usage de physostigmine, ce qui trahit une étiologie différente. Suite à une anesthésie de 50 minutes au thiopental, fentanyl $(100 \mu \mathrm{g})$, enflurane et protoxyde d'azote et la détubation de la trachée après retour de la conscience, une jeune femme présenta un opisthotonos. Quarante $\mathrm{mg}$ de thiopental, $5 \mathrm{mg}$ de diazépam et $50 \mathrm{mg}$ de diphenhydramine parvinrent à contrer l'opisthotonos qui réapparu 25 minutes plus tard associé cette fois à un torticolis, de la stupeur et des pauses respiratoires. Avec un diagnostic présomptif de syndrome anticholinergique central attribuable au fentanyl, on essaya sans résultat $0,4 \mathrm{mg}$ de naloxone. Deux $\mathrm{mg}$ de physostigmine suffirent à faire disparaître la dystonie et les pauses respiratoires et à améliorer l'état de conscience de la patiente. Cette réponse à la physostigmine peut être attribuable à une augmentation la quantité d'acétylcholine sur les récepteurs cholinergiques ou à un effet analeptique non-spécifique.

The unusual phenomenon of opisthotonus has recently been reported in the postoperative period after anaesthetics performed with propofol. ${ }^{1-5}$ Also, postoperative myoclonic symptoms have been reported after the use of several inhalational anaesthetic agents, induction drugs, and narcotics. ${ }^{6-11}$ Review of these reports revealed that postoperative myoclonic symptoms were frequently, but not always associated with the use of central excitatory drugs, such as propofol, enflurane, or etomidate, and were associated with the administration of potent narcotics. We report a patient who developed opisthotonus after anaesthesia.

\section{Case report}

A healthy, 32-yr-old, $59 \mathrm{~kg}$, white female outpatient required surgical drainage of a breast abscess that had not responded to conservative treatment with antibiotics. She had a medical history of mitral and tricuspid valve prolapse, diagnosed by echocardiography. Nonexertional dyspnoea and chest tightness occurred occasionally, but 
neither palpitations nor exercise intolerance were present. She had no history of seizures. Her only current medication was oral erythromycin for therapy of acne. She had a 14 pack-year smoking history and rarely used alcohol. She denied substance abuse at preoperative and postoperative interviews. She was employed as a psychiatric nurse. Two previous anaesthetics were uncomplicated.

Physical examination demonstrated a small left breast abscess and a left parasternal midsystolic click, which was accentuated by squatting. Preoperative electrocardiogram, complete blood count, and serum electrolytes were within normal limits.

Vital signs in the operating room were: blood pressure (BP) $130 / 80 \mathrm{mmHg}$, heart rate (HR) 70 beats $\cdot \mathrm{min}^{-1}$, respiratory rate (RR) 16 breaths $\cdot \mathrm{min}^{-1}$ and oral temperature $37^{\circ} \mathrm{C}$. Lactated Ringer's solution $(800 \mathrm{ml})$ was infused with cefazolin (19) and gentamicin $(80 \mathrm{mg}$ ) for endocarditis prophylaxis. Preinduction drugs included oxygen, d-tubocurarine ( $3 \mathrm{mg}$ ), lidocaine (100 $\mathrm{mg}$ ), and fentanyl $(100 \mathrm{mg})$. Tracheal intubation was performed after thiopentone $(300 \mathrm{mg})$, succinylcholine $(100 \mathrm{mg})$, and enflurane (2\%) in oxygen. Anaesthesia was maintained with enflurane $(1-2 \%)$ in $50 \%$ nitrous oxide $\left(\mathrm{N}_{2} \mathrm{O}\right)$ and oxygen. Her BP ranged from 110-130/60-80 $\mathrm{mmHg}$, $\mathrm{HR} 70-80$, and end tidal $\mathrm{PCO}_{2}\left(\mathrm{PETCO}_{2}\right)$ from $35-40 \mathrm{mmHg}$, with assisted manual ventilation. Her trachea was extubated after $50 \mathrm{~min}$ of anaesthesia, when she obeyed commands and maintained a $\mathrm{PETCO}_{2}$ of 42 $\mathrm{mmHg}$ with spontaneous ventilation.

Opisthotonus developed during transport to the postanaesthesia care unit (PACU). Her back and pelvis arched approximately 4-6 inches off the stretcher, and her extremities were extended. She was returned to the operating room for oxygen administration and evaluation. Vital signs were unchanged. She breathed 20 breaths $\cdot \min ^{-1}$, without airway obstruction. The posturing recurred every one to two minutes. Because the muscular activity resembled a seizure, thiopentone (40 $\mathrm{mg}$ ) and diazepam (5 mg) were infused and the opisthotonus resolved. Previous ingestion of phenothiazine-like drugs, with central cholinergic side-effects, was also considered, so diphenhydramine $(50 \mathrm{mg})$ was administered.

The patient was returned to the PACU and initially was unresponsive. Mild horizontal and vertical nystagmus were noted $15 \mathrm{~min}$ after the initial onset of opisthotonus. The opisthotonus recurred ten minutes after return to the PACU, with spasms then developing every three to five minutes. In addition, intermittent torticollis (contraction of neck muscles with twisting of the neck and head) started. Recurrent episodes of intermittent apnoea lasting $10-15 \mathrm{sec}$ developed after $20 \mathrm{~min}$ in the PACU. The RR varied between $6-16$ breaths $\cdot \mathrm{min}^{-1}$, but she followed commands to breathe. She was lethargic and without spontaneous motor movement. Arterial blood gas analysis $\left(\mathrm{FlO}_{2} 50 \%\right)$ demonstrated $\mathrm{pH} 7.39, \mathrm{PaOi}_{2} 217 \mathrm{mmHg}$, and $\mathrm{PaCO}_{2} 44 \mathrm{mmHg}$. Serum concentrations of electrolytes, glucose, calcium, phosphorous, and magnesium were normal.

A neurologist evaluated the patient within $30 \mathrm{~min}$ of entry into the PACU. He found external ophthalmoplegia in all directions, reactive pupils $(3-4 \mathrm{~mm})$, symmetrical, 3-4 + deep tendon reflexes, absence of clonus, and normal flexor plantar reflexes. Diffuse hypotonia was present between myoclonic contractions. The symptoms were attributed to central anticholinergic syndrome, probably induced by the fentanyl. Naloxone $(0.4 \mathrm{mg})$ was given slowly $i v$, but it produced no improvement in 20 $\mathrm{min}$. The tertiary anticholinesterase inhibitor physostigmine $(2 \mathrm{mg})$ was slowly infused. The periodic apnoea, opisthotonus, and torticollis resolved over several minutes. The RR also increased to $12-16$ breaths $\cdot \mathrm{min}^{-1}$, and the HR decreased to $60-70$ beats $\cdot \mathrm{min}^{-1}$. The patient became more alert, expressed no complaints, and talked to her husband.

She was lethargic but arousable and oriented after admission to a closely monitored ward area. Mild nystagmus and muscular hypotonia persisted, but no muscular spasms recurred. Previous substance or drug abuse, topical exposure to antipsychotic medications, or ingestion of "over the counter" drugs were denied during extensive questioning the next day. She received a letter that listed the drugs administered and described her idiosyncratic reaction. Neurological evaluation two weeks later was normal.

\section{Discussion}

Our patient appears to be the first case of opisthotonus and torticollis following an anaesthetic that did not include propofol or drugs that produce extrapyramidal symptoms by antagonism of dopaminergic receptors (phenothiazine, droperidol, or metoclopramide). The contribution of other drugs administered to our patient and the possible role of central cholinergic receptors and potent narcotics are discussed, including details of the other reported cases of postanaesthesia myoclonus.

The dramatic extrapyramidal system (EPS) symptoms of opisthotonus, torticollis, and nystagmus, in conjunction with periodic apnoea and mental obtundation, were attributed to the central anticholinergic syndrome. Central anticholinergic syndrome can present after anaesthesia with mental obtundation or excitation. ${ }^{12-14}$ Extrapyramidal symptoms are not a typical presentation but myoclonus, choreoathetosis, "truncal writhing and pelvic arching," symmetric decorticate posturing, and decreased muscle tone have been reported after overdoses of 
tricyclic antidepressants (imipramine hydrochloride, amitriptyline) or angel's trumpet (Jimson weed). Physostigmine reversed these myoclonic and dystonic symptoms in the patients with the reported overdoses. ${ }^{15,16}$

Physostigmine has been utilized to antagonize sedation or delirium from anaesthetic drugs with central anticholinergic effects, such as atropine, scopolamine, phenothiazines, droperidol or antihistamines. ${ }^{12,13}$ However, drugs with central nervous system (CNS) anticholinergic activity $^{14,17}$ were not administered to our patient, except for the diphenhydramine given after the opisthotonus started.

Physostigmine not only reverses central anticholinergic symptoms, but may also possess nonspecific analeptic properties. Physostigmine has reversed benzodiazepineinduced sedation ${ }^{18,19}$ and hastened recovery from halothane and $\mathrm{N}_{2} \mathrm{O}$ anaesthesia in patients premedicated with atropine and secobarbital. ${ }^{20}$ Physostigmine has also reversed postoperative morphine-induced respiratory depression, without impairing analgesia, probably due to physostigmine's anticholinergic action in the medulla. ${ }^{21}$ However, physostigmine did not alter morphine-induced respiratory depression in unpremedicated volunteers. ${ }^{19}$

Excitatory CNS phenomena following general anaesthesia have been documented previously. Hyperreflexia, positive Babinski signs, or sustained ankle clonus developed in $50 \%$ of patients receiving enflurane and $\mathrm{N}_{2} \mathrm{O}$ and in $25 \%$ of patients given halothane and $\mathrm{N}_{2} \mathrm{O} \cdot{ }^{22}$ Certain anaesthetic agents may be more likely to induce postoperative CNS excitatory phenomena, including opisthotonus.

The role of individual perioperative drugs in causing the postoperative EPS symptoms needs to be considered. Enflurane possesses persistent, excitatory postoperative CNS effects. Reversible, mild electroencephalogram abnormalities occurred for 6-30 days after enflurane anaesthesia. ${ }^{23}$ Seizures that developed days after enflurane anaesthesia were also attributed circumstantially, to enflurane. ${ }^{24,25}$

Volunteers receiving $\mathrm{N}_{2} \mathrm{O}$ in a hyperbaric chamber (1.55 atm) demonstrated myoclonic movements, and one subject developed opisthotonus. ${ }^{26}$ Mice developed jerking, grimacing, and excitation after cessation of $\mathrm{N}_{2} \mathrm{O}$. These withdrawal symptoms were considered analogous to central anticholinergic syndrome, and physostigmine reversed the symptoms in mice. ${ }^{27}$ The complexity of the interactions is demonstrated by the observation, in mice, that naloxone pretreatment could prevent the excitatory symptoms, but that naloxone post-treatment could not. ${ }^{27}$ Enflurane and $\mathrm{N}_{2} \mathrm{O}$ have potential postoperative effects, which could have contributed to our patient's symptoms.

Synthetic narcotics, such as meperidine, with its "atropine-like" structure, may induce the central anticholinergic syndrome. ${ }^{28}$ However, muscular rigidity is a more common neuromuscular complication following potent narcotic infusion. Electroencephalographic studies have demonstrated that the narcotic-induced rigidity was not associated with seizures, despite the extremely rapid onset of tonic-clonic movement and association with nystagmus. ${ }^{29,30}$ Postoperative rigidity has occurred 3-24 hr after fentanyl $\left(35-100 \mu \mathrm{g} \cdot \mathrm{kg}^{-1}\right)$, in association with recrudescence of high plasma concentrations of fentanyl. Naloxone reversed this postoperative rigidity. ${ }^{31-35}$ However, narcotic-induced rigidity is an unlikely explanation for our patient's postoperative myoclonic symptoms, since she received an extremely low dose of fentanyl, had EPS symptoms and underlying hypotonia, and did not respond to naloxone.

Definitions and a differential diagnosis for dystonia and myoclonus are provided to help the aetiology of our patient's symptoms to be understood. Dystonic movements are involuntary movements that typically involve twisting movements of single or multiple parts of the body. The basal ganglia are the site of abnormality. ${ }^{36}$ The differential diagnosis includes chronic neurological disorders (hereditary dystonia, Wilson's disease, Hallervorden-Spatz disease) and secondary dystonias, such as cerebral injury or tumour, CNS infections, toxicity from carbon monoxide or manganese, or drug-induced (levodopa, antipsychotics, metoclopramide, anticonvulsants) effects. ${ }^{37}$ Our patient had no history of CNS disorders and had a normal neurological evaluation two weeks after the anaesthetic. Unacknowledged exposure to medicinal or recreational drugs was excluded by history from this intelligent, responsible patient. However, a toxicology screen was not performed on our patient or in any of the other reported patients with movement disorders. ${ }^{1-11}$

Myoclonus is characterized by either irregular or rhythmic muscle jerks, and it can either be epileptic or nonepileptic. Our patient's symptoms were not felt to be characteristic of seizures, due to EPS symptoms and periodic apnea. Myoclonus has a diffuse aetiology and can arise from a cortical, subcortical, or brainstem abnormality. The differential diagnosis for myoclonus includes encephalopathies from viral, toxic (heavy metals, strychnine), and metabolic causes (hypoxia, hypoglycaemia, or uraemia), storage diseases, basal ganglia or spinocerebellar degeneration, ${ }^{36}$ and drugs (etomidate, ketamine, enflurane, levodopa, tricyclic antidepressants, lithium, and monoamine oxidase inhibitors, and toxic concentrations of cephalosporins and penicillins). ${ }^{38}$ None of these factors was present in our patient.

The drugs and circumstances of the reported cases of postoperative myoclonus, not involving propofol, are summarized (Table I). ${ }^{6-11}$ One case of myoclonic, postoperative symptoms has been reported after enflurane. However, the patient had focal symptoms, with right-sided headache and otalgia, a subjective feeling of 
TABLE I Postoperative myoclonus after anaesthesia

\begin{tabular}{|c|c|c|c|c|c|}
\hline $\begin{array}{l}\text { Age, sex, } \\
\text { procedure }\end{array}$ & Inhalation & $\begin{array}{l}\text { Pre-, intra-operative } \\
\text { drugs }\end{array}$ & Narcotics & PACU symptoms & Diagnosis, treatment \\
\hline $\begin{array}{l}38, \text { female, } \\
\text { knee arthroscopy }\end{array}$ & $\begin{array}{l}\text { enflurane } \\
\mathrm{N}_{2} \mathrm{O}\end{array}$ & *thiopentone $375 \mathrm{mg}$ iv & - & $\begin{array}{l}\text { Awake for } 30 \text { min then } \\
\text { global myoclonic jerking } \\
\text { which localized to left side } \\
\text { for } 48 \mathrm{hr}\end{array}$ & - \\
\hline $\begin{array}{l}69, \text { female }^{7} \\
\text { knee arthroscopy }\end{array}$ & $\begin{array}{l}\text { isoflurane } \\
\mathrm{N}_{2} \mathrm{O}\end{array}$ & thiopentone $350 \mathrm{mg}$ iv & - & $\begin{array}{l}\text { Initially awake then upper } \\
\text { extremity myoclonus } \\
20 \text { min after entry to PACU, } \\
\text { responded to drugs }\end{array}$ & $\begin{array}{l}\text { diazepam } 10 \mathrm{mg} \text {, iv, twice } \\
\text { diphenylhydantoin } 400 \mathrm{mg} \\
i v\end{array}$ \\
\hline $\begin{array}{l}27, \text { male }{ }^{8} \text { hip } \\
\text { synovectomy }\end{array}$ & $\begin{array}{l}\text { isoflurane } \\
\mathrm{N}_{2} \mathrm{O}\end{array}$ & $\begin{array}{l}\text { diazepam } 10 \mathrm{mg} \mathrm{po} \\
\text { glycopyrolate } 0.2 \mathrm{mg} \mathrm{im} \\
\text { *thiopentone } 400 \mathrm{mg} \mathrm{iv}\end{array}$ & $\begin{array}{l}\text { morphine } 10 \mathrm{mg} \mathrm{im} \\
\text { fentanyl } 100 \mathrm{mcg} i v \\
\text { preop and } 100 \mu \mathrm{g} \mathrm{iv} \\
\text { intraop }\end{array}$ & $\begin{array}{l}\text { Global myoclonic move- } \\
\text { ments starting intraop after } \\
\text { fentanyl. Postop lower } \\
\text { extremity myoclonus for } \\
>1 \mathrm{hr}\end{array}$ & $\begin{array}{l}\text { thiopentone } 150 \mathrm{~m} \mathrm{iv} \\
\text { intraop }\end{array}$ \\
\hline $\begin{array}{l}45, \text { female, } \\
\text { D\&C }\end{array}$ & - & $\begin{array}{l}\text { scopolamine } 0.2 \mathrm{mg} \mathrm{im} \\
\text { etomidate } 35 \mathrm{mg} i \mathrm{v}\end{array}$ & $\begin{array}{l}\text { papaveretum } 10 \mathrm{mg} \text { im } \\
\text { fentanyl } 150 \mu \mathrm{g} i \mathrm{v}\end{array}$ & $\begin{array}{l}\text { Initially awake then global } \\
\text { clonic movements for } \\
90 \mathrm{sec}, \text { resolved with drug } \\
\text { therapy }\end{array}$ & diazepam $10 \mathrm{mg}$ iv \\
\hline $\begin{array}{l}75, \text { male, } \\
\text { lumbar } \\
\text { laminectomy }\end{array}$ & $\mathrm{N}_{2} \mathrm{O}$ & $\begin{array}{l}\text { diphenhydramine } 50 \mathrm{mg} \\
\text { im } \\
\text { *etomidate } 26 \mathrm{mg} \mathrm{iv} \\
\text { induction and } 324 \mathrm{mg} \\
\text { continuous infusion }\end{array}$ & $\begin{array}{l}\text { fentanyl } 475 \mu \mathrm{g} i v \\
\text { infusion }\end{array}$ & $\begin{array}{l}\text { Global myoclonus for } \\
2.5 \mathrm{hr} \text {, resolved as patient } \\
\text { gained consciousness }\end{array}$ & - \\
\hline $\begin{array}{l}\text { 35, female, } \\
\text { C-section }\end{array}$ & - & $\begin{array}{l}\text { epidural lidocaine } 2 \% \\
\text { with epinephrine } \\
\text { atropine } 0.4 \mathrm{mg} \mathrm{iv} \\
\text { droperidol } 1.25 \mathrm{mg} \text { iv }\end{array}$ & $\begin{array}{l}\text { fentanyl } 100 \mu \mathrm{g} \text { iv } \\
\text { epidural fentanyl } \\
100 \mathrm{mcg} \text { bolus and } \\
\text { infusion } 50 \mu \mathrm{g} / \mathrm{hr} \\
\text { postop }\end{array}$ & $\begin{array}{l}\text { Asympotomatic for hours } \\
\text { then global myoclonus, } \\
\text { lethargy, delirium, } \\
\text { nystagmus, responded to } \\
\text { drug therapy }\end{array}$ & $\begin{array}{l}\text { physostigmine } 2 \mathrm{mg} \text { iv } \times 2 \\
\text { doses, CT normal }\end{array}$ \\
\hline
\end{tabular}

*Patients who received succinylcholine and/or nondepolarizing muscle relaxants with reversal; D\&C = dilation and curettage; PACU = post-anaesthesia care unit; $\mathrm{N}_{2} \mathrm{O}=$ nitrous oxide; $\mathrm{CT}=$ computerized tomography.

left-sided weakness, persistence of myoclonus for $48 \mathrm{hr}$, with no definite exclusion of CNS pathology. ${ }^{6}$ Postoperative upper extremity myoclonus has been ascribed to isoflurane. ${ }^{7}$ Intraoperative global myoclonic movements started after fentanyl $(100 \mu \mathrm{g})$ was given during an isoflurane anaesthetic, with continuation of lower extremity myoclonus for more than one hr postoperatively. ${ }^{8}$ Postoperative myoclonus also developed after anaesthetics performed with infusion of fentanyl and the CNS excitatory drug etomidate (premedication included drugs with anticholinergic properties). ${ }^{9,10}$ A patient, undergoing a Caesarean section with epidural analgesia, received fentanyl and drugs with anticholinergic properties (droperidol and atropine). Epidural fentanyl was administered in the postoperative period. ${ }^{11}$ This obstetrical patient was lucid and asymptomatic for three hours, but myoclonus and delirium developed one hour after discharge from the
PACU. Physostigmine improved her mental status and reversed the myoclonus, but coarse tremors persisted. ${ }^{11}$

Dystonia, or more specifically opisthotonus, has been recently reported following propofol anaesthesia (Table II). ${ }^{1-5}$ However, some of the patients developing opisthotonus after propofol also had a history of seizures ${ }^{2,4}$ or received drugs with central anticholinergic properties (atropine ${ }^{1,4,5}$ or droperidol ${ }^{3}$ ). The British Committee on Safety of Medicine reported that propofol has been associated with ten cases of opisthotonus, 16 cases of involuntary movements, and 37 cases of seizures ( 13 of the last had seizure histories). ${ }^{40}$

The exact cause of our patient's opisthotonus and torticollis and the other patients' myoclonic or dystonic symptoms cannot be determined retrospectively. Our patient's response to physostigmine does not definitely confirm central anticholinergic syndrome, since physo- 
TABLE II Postoperative myoclonus with propofol

\begin{tabular}{|c|c|c|c|c|c|}
\hline $\begin{array}{l}\text { Age, sex, } \\
\text { procedure }\end{array}$ & Inhalation & $\begin{array}{l}\text { Pre-, intra-operative } \\
\text { drugs }\end{array}$ & Narcotics & PACU symptoms & Diagnosis, treatment \\
\hline $\begin{array}{l}\text { 44, female, } \\
\text { D\&C }\end{array}$ & $\begin{array}{l}\text { enflurane } \\
\mathrm{N}_{2} \mathrm{O}\end{array}$ & $\begin{array}{l}\text { atropine } 0.3 \mathrm{mg} i v \\
\text { propofol } 114 \mathrm{mg} i v\end{array}$ & alfentanil $500 \mu \mathrm{g} i v$ & $\begin{array}{l}\text { Nystagmus, hyperreflexia } \\
\text { ankle clonus, opisthotonus, } \\
\text { weakness, sedated for } 5 \mathrm{hr} \text {. } \\
\text { Symptoms on right side at } \\
10 \mathrm{hr}\end{array}$ & EEG, CT, and LP normal \\
\hline $\begin{array}{l}24, \text { female, } \\
\text { laparoscopy }\end{array}$ & $\begin{array}{l}\text { enflurane } \\
\mathrm{N}_{2} \mathrm{O}\end{array}$ & $\begin{array}{l}\text { atropine } 0.3 \mathrm{mg} \mathrm{iv} \\
{ }^{*} \text { propofol } 114 \mathrm{mg} \text { iv }\end{array}$ & alfentanil $500 \mu \mathrm{g} i \mathrm{v}$ & $\begin{array}{l}\text { Jerky movements, hyper- } \\
\text { tonicity, hyperreflexia, } \\
\text { ankle clonus, nystagmus. } \\
\text { Sedated for } 1 \mathrm{hr} \text {. }\end{array}$ & EEG normal \\
\hline $\begin{array}{l}21, \text { female }{ }^{1} \\
\text { laparoscopy }\end{array}$ & $\begin{array}{l}\text { enflurane } \\
\mathrm{N}_{2} \mathrm{O}\end{array}$ & $\begin{array}{l}\text { atropine } 0.3 \mathrm{mg} \mathrm{iv} \\
\text { *propofol } 133 \mathrm{mg} \text { iv }\end{array}$ & alfentanil $500 \mu \mathrm{g} i v$ & $\begin{array}{l}\text { Initially awake then extensor } \\
\text { jerks in all four limbs, } \\
\text { hyperreflexia, hypertonicity }\end{array}$ & EEG normal \\
\hline $\begin{array}{l}26, \text { female }{ }^{1} \\
\text { myringotomies, } \\
\text { seizure } \mathrm{Hx}\end{array}$ & $\begin{array}{l}\text { isoflurane } \\
\mathrm{N}_{2} \mathrm{O}\end{array}$ & propofol $150 \mathrm{mg} i \mathrm{v}$ & - & $\begin{array}{l}\text { Gasping then apnoeic, } \\
\text { opisthotonus for } 15-30 \mathrm{sec} \\
\text { at three times, then awake }\end{array}$ & - \\
\hline $\begin{array}{l}20, \text { female }{ }^{2} \\
\text { D\&C }\end{array}$ & - & $\begin{array}{l}\text { temazepam } 20 \mathrm{mg} \text { po } \\
\text { propofol } 140 \mathrm{mg} \text { iv }\end{array}$ & alfentanil $750 \mu \mathrm{g} i v$ & $\begin{array}{l}\text { Awake then opisthotonus } \\
\times 7 \text {, triggered by noise and } \\
\text { movement }\end{array}$ & $\begin{array}{l}\text { Diazemuls } 10 \mathrm{mg} i v \text { with } \\
\text { response }\end{array}$ \\
\hline $\begin{array}{l}55, \text { female, } \\
\text { D\&C }\end{array}$ & $\mathrm{N}_{2} \mathrm{O}$ & $\begin{array}{l}\text { droperidol } 2.5 \mathrm{mg} \text { iv } \\
\text { propofol } 95 \mathrm{mg}\end{array}$ & alfentanil $250 \mu \mathrm{g} i v$ & $\begin{array}{l}\text { Violent writhing, } \\
\text { opisthotonus, "marked" } \\
\text { extrapyramidal signs, } \\
\text { oculogyric crisis }\end{array}$ & $\begin{array}{l}\text { procyclidine } 10 \mathrm{mg} \mathrm{i}, \\
\text { chlormethiazole infusion, } \\
\text { EEG and brain scan normal }\end{array}$ \\
\hline $\begin{array}{l}\text { 44, female, }{ }^{4} \\
\text { D\&C, Seizure Hx }\end{array}$ & $\mathrm{N}_{2} \mathrm{O}$ & $\begin{array}{l}\text { atropine } 0.5 \mathrm{mg} \text {, im } \\
\text { propofol } 260 \mathrm{mg} \text { iv }\end{array}$ & $\begin{array}{l}\text { meperidine } 50 \mathrm{mg} \text { im } \\
\text { preop } \\
\text { fentanyl } 50 \mu \mathrm{g} i \mathrm{v}\end{array}$ & $\begin{array}{l}\text { Initially normal, } \\
\text { opisthotonus, myoclonic } \\
\text { movement limbs, rightsided } \\
\text { weakness, grand mal } \\
\text { seizure five hr later }\end{array}$ & $\begin{array}{l}\text { thiopentone } 75 \mathrm{mg} \text { short } \\
\text { respite from myoclonus, } \\
\text { diazepam } 2.5 \mathrm{mg} \text { and } \\
\text { phenytoin to treat seizure }\end{array}$ \\
\hline $\begin{array}{l}29, \text { female, },^{5} \text { toe } \\
\text { arthrodesis }\end{array}$ & $\begin{array}{l}\text { enflurane } \\
\mathrm{N}_{2} \mathrm{O}\end{array}$ & $\begin{array}{l}\text { atropine } 0.6 \mathrm{mg} \mathrm{im} \\
\text { propofol } 150 \mathrm{mg} \\
\text { ankle block with } \\
\text { bupivicaine } 61.5 \mathrm{mg}\end{array}$ & morphine $10 \mathrm{mg}$ im & $\begin{array}{l}\text { Initially obeyed commands, } \\
\text { opisthotonus followed by } \\
\text { grand mal "seizure" with } \\
\text { recurrent tonic-clonic } \\
\text { "seizures", opisthotonic for } \\
23 \text { days }\end{array}$ & $\begin{array}{l}\text { Diazemuls } 10 \mathrm{mg} i v \text {, Brain } \\
\text { scan, CT, LP, and EEG } \\
\text { normal }\end{array}$ \\
\hline
\end{tabular}

*Patients that received succinylcholine and/or nondepolarizing muscle relaxants with reversal; $\mathrm{Hx}=$ History; PACU = post-anaesthesia care unit; $\mathrm{D} \& \mathrm{C}=$ dilation and curettage; $\mathrm{N}_{2} \mathrm{O}=$ nitrous oxide; $\mathrm{CT}=$ computerized tomography; $\mathrm{LP}=$ lumbar puncture; $\mathrm{EEG}=$ electroencephalogram.

stigmine has direct receptor mediated effects and indirect analeptic effects. Our experience indicates that physostigmine should probably be considered for treatment of opisthotonus or other CNS dystonic postoperative phenomena, if seizure, metabolic cause, CNS disease, and use of drugs that antagonize dopamine receptors can be excluded.

It is not known if narcotics potentiate postoperative CNS excitatory phenomena, such as opisthotonus and myoclonus. However, a circumstantial association is suggested since fentanyl or alfentanil was utilized in four of the six reported cases of myoclonus not involving propofol $^{8-11}$ and in six of the eight reported cases of opisthotonus after propofol. ${ }^{1-4}$ As discussed, synthetic narcotics such as meperidine can cause central anticholinergic syndrome. ${ }^{28}$ Abundant animal research has shown the protean alterations in neurological mediator production and release following narcotics. Some of the mechanisms involved with narcotic-induced rigidity in animal models have been summarized. ${ }^{39}$ 
Extremely rare phenomena such as EPS symptoms after thiopentone, enflurane, fentanyl, and $\mathrm{N}_{2} \mathrm{O}$ are difficult or impossible to study prospectively. Hopefully, the 37 cases reported of opisthotonus after propofol in Britain ${ }^{40}$ will lead to prospective studies to examine the mechanism and to determine if potent narcotics are involved and if appropriate therapy includes physostigmine.

\section{References}

1 Saunders PRI, Harris MNE. Opisthotonus and other unusual neurological sequelae after outpatient anaesthesia. Anaesthesia 1990; 45: 552-7.

2 Strowbridge NF. Postoperative opisthotonus following the use of propofol. J R Army Med Corps 1989; 135 : 79-80.

3 Dingwall $A E$. Oculogyric crisis after day case anaesthesia (Letter). Anaesthesia 1987; 42: 565.

4 Cameron $A E$. Opisthotonos again (Letter). Anaesthesia 1987; 42: 1124.

5 Hopkins CS. Recurrent opisthotonus associated with anaesthesia (Letter). Anaesthesia 1988; 43: 904.

$6 \mathrm{Ng} \mathrm{ATH}$. Prolonged myoclonic contractions after enflurane anaesthesia - a case report. Can Anaesth Soc J 1980; 27: 502-3.

7 Harrison JL. Postoperative seizures after isoflurane anesthesia. Anesth Analg 1986; 65: 1235-6.

8 Hymes $J A$. Seizure activity during isoflurane anesthesia. Anesth Analg 1985; 64: 367-8.

9 Goroszeniuk T, Albin M, Jones FM. Generalized grand mal seizure after recovery from uncomplicated fentanyletomidate anesthesia. Anesth Analg 1986; 65: 979-81.

10 Laughlin TP, Newberg LA. Prolonged myoclonus after etomidate anesthesia. Anesth Analg 1985; 64: 80-2.

11 Weinger $M B$, Swerdlow NR, Millar WL. Acute postoperative delirium and extrapyramidal signs in a previously healthy parturient. Anesth Analg 1988; 67: 291-5.

12 Brebner J, Hadley $L$. Experiences with physostigmine in the reversal of adverse post-anaesthetic effects. Can Anaesth Soc J 1976; 23: 574-81.

13 Bidwai AV, Cornelius LR, Stanley TH. Reversal of Innovar-induced postanesthetic somnolence and disorientation with physostigmine. Anesthesiology 1976; 44 : 249-52.

14 Rumack BH. Anticholinergic poisoning: treatment with physostigmine. Pediatrics 1973; 52: 449-51.

15 Burks $J S$, Walker $J E$, Rumack $B H$, Ott $J E$. Tricyclic antidepressant poisoning: reversal of coma, choreoathetosis, and myoclonus by physostigmine. JAMA 1974; 230: 1405-7.

16 Hall RCW, Popkin MK, McHenry LE. Angel's trumpet psychosis: a central nervous system anticholinergic syndrome. Am J Psychiatry 1977; 134: 312-4.
17 Flacke WE, Flacke JW. Cholinergic and anticholinergic agents. In: Smith NT, Carbascio AN (Eds.). Drug Interactions in Anesthesia, Philadelphia: Lea \& Febiger, 1986: 160-75.

18 Caldwell CB, Cross JB. Physostigmine reversal of midazolam-induced sedation. Anesthesiology 1982; 57: 125-7.

19 Bourk $D L$, Rosenberg $M$, Allen PD. Physostigmine: effectiveness as an antagonist of respiratory depression and psychomotor effects caused by morphine or diazepam. Anesthesiology 1984; 61: 523-8.

20 Hill CL, Stanley TH, Sentker CR. Physostigmine reversal of postoperative somnolence. Can Anaesth Soc J 1977; 24: 707-11.

21 Weinstock $M$, Davidson JT, Rosin AJ, Schnieden $H$. Effects of physostigmine on morphine-induced postoperative pain and somnolence. Br J Anaesth 1982; 54: 429-34.

22 Rosenberg $H$, Clofine $R$, Bialik $O$. Neurologic changes during awakening from anesthesia. Anesthesiology 1981; 54: 125-30.

23 Burchiel KJ, Stockard JJ, Calverley RK, Smith NT. Relationship of pre- and postanesthetic EEG abnormalities to enflurane-induced seizure activity. Anesth Analg 1977; 56: 509-14.

24 Ohm WW, Cullen BF, Amory DW, Kennedy RD. Delayed seizure activity following enflurane anesthesia. Anesthesiology $1975 ; 42: 367-8$.

25 Kruczek M, Albin MS, Wolf S, Bertoni JM. Postoperative seizure activity following enflurane anesthesia. Anesthesiology 1980 ; 53: 175-6.

26 Hornbein TF, Eger EI, Winter PM, Smith G, Westone D, Smith $K H$. The minimum alveolar concentration of nitrous oxide in man. Anesth Analg 1982; 61: 553-6.

27 Rupreht J, Dworacek B, Ducardus R, Schmitz PIM, Dzoljic $M R$. The involvement of the central cholinergic and endorphinergic systems in the nitrous oxide withdrawal syndrome in mice. Anesthesiology 1983; 58: 524-6.

28 Durrett $L R$, Lawson $N W$. Autonomic nervous system physiology and pharmacology. In: Barash PG, Cullen BF, Stoelting RK (Eds.). Clinical Anesthesia. Philadelphia: Lippincott Co, 1989: 165-226.

29 Benthuysen JL, Smith NT, Sanford TJ, Head N, Dec-Silver $H$. Physiology of alfentanil-induced rigidity. Anesthesiology 1986; 64: 440-6.

30 Smith NF, Benthuysen JL, Bickford RG et al. Seizures during opioid anesthetic induction - are they opioidinduced rigidity? Anesthesiology 1989; 71: 852-62.

31 Mirenda J, Tabatabai $M$, Wong $K$. Delayed and prolonged rigidity greater than $24 \mathrm{~h}$ following high-dose fentanyl anesthesia. Anesthesiology 1988; 69: 624-5. 
32 Stoeckel H, Hengstmann JH, Schuttler J. Pharmacokinetics of fentanyl as a possible explanation for recurrence of respiratory depression. Br J Anaesth 1979; 51: 741-5

33 Christian CM, Waller JL, Moldenhauer CC. Postoperative rigidity following fentanyl anesthesia. Anesthesiology $1983 ; 58$ : 275-7.

34 Caspi J, Klausner JM, Safadi T, Amar R, Rozin RR, Merin $G$. Delayed respiratory depression following fentanyl anesthesia for cardiac surgery. Crit Care Med 1988; 16 : 238-40.

35 Klausner JM, Caspi J, Lelcuk S, Khazam A, Marin G, Hechtman $H B$, Rozin $R R$. Delayed muscular rigidity and respiratory depression following fentanyl anesthesia. Arch Surg 1988; 123: 66-7.

36 Hallett $M$, Ravits $J$. Involuntary movements. In: Asbury AK, McKhann GM, McDonald WI (Eds.). Diseases of the Nervous System Clinical Neurobiology, Philadelphia, WB Saunders, 1986: 452-60.

37 Fahn S, Jankovic J. Practical management of dystonia. In: Jankovic J (Ed.). Neurologic Clinics - Movement Disorders, Philadelphia: WB Saunders, 1984: 555-69.

38 Klawans HL, Carvey PM, Tanner CM, Goetz CG. Druginduced myoclonus. In: Fahn $\mathrm{S}$ (Ed.). Advances in Neurology, Vol 43, Myoclonus, New York: Raven Press, 1986, 251-64.

39 Weinger MB, Segal IS, Maze M. Dexmedetomidine, acting through central alpha- 2 adrenoceptors, prevents opiate-induced muscle rigidity in the rat. Anesthesiology 1989; 71: 242-9.

40 Committee of Safety of Medicines. Propofol - convulsions, anaphylaxis and delayed recovery from anaesthesia. Current Problems 1989; 26: 2-3. 